\title{
Monte Carlo Simulation of 6 MV Flattening Filter Free Photon Beam of TrueBeam STx LINAC at Songklanagarind Hospital
}

(Simulasi Monte Carlo 6 MV Perataan Tanpa Penurasan Alur Foton TrueBeam STx LINAC di Hospital Songklanagarind)

\author{
M. ARIF EFENDI, AMPORN FUNSIAN, THAWAT CHITTRAKARN \& TRIPOB BHONGSUWAN*
}

\begin{abstract}
In this study, 6 MV photon beam of TrueBeam STx Varian LINAC with Flattening Filter Free (FFF) was simulated using PRIMO code. The depth dose profiles for various jaws open fields and cross beam profiles for various depths inside water phantom were determined using Monte Carlo $(M C)$ simulation technique and validated with experimental result. The experiments were performed using the Source to Surface Distance (SSD) technique with a $100 \mathrm{~cm}$ distance from target to the surface of water. Simulation used $10^{9}$ histories with the same configurations with experiments. The depth dose profiles and cross beam profiles of 6 MVFFF photon beam was determined using MC simulations and compared with experimental results. The results showed that depth dose profiles and cross beam profiles by MC simulation accurately matched with experimental results. The best result of depth dose profile was obtained at $10 \times 10 \mathrm{~cm}^{2}$ jaws open field with $98.53 \%$ passing criterion whereas cross beam profile was obtained at $10 \mathrm{~cm}$ depth inside water phantom with $88.96 \%$ passing criterion. The discrepancies were caused by scatter of particle and incompatibility of primary beam in PRIMO with experiment.
\end{abstract}

Keywords: Flattening Filter Free (FFF); Linear Accelerator (LINAC); Monte Carlo simulation; PRIMO Code

\section{ABSTRAK}

Dalam kajian ini, 6 MV alur foton daripada TrueBeam STx Varian LINAC dengan perataan tanpa penurasan (FFF) disimulasikan menggunakan kod PRIMO. Profil kedalaman dos untuk pelbagai ukuran rahang dan profil melintang alur untuk pelbagai kedalaman dalam fantom air telah ditentukan dengan menggunakan teknik simulasi Monte Carlo (MC) dan disahkan secara eksperimen. Uji kaji telah dijalankan dengan menggunakan teknik jarak sumber kepada permukaan (SSD) dengan jarak $100 \mathrm{~cm}$ dari sasaran ke permukaan air. Simulasi menggunakan $10^{9}$ peristiwa, konfigurasi yang sama dengan uji kaji. Profil kedalaman dos dan profil melintang alur daripada 6 MV FFF alur foton ditentukan dengan menggunakan simulasi MC dan dibandingkan dengan keputusan uji kaji. Hasil kajian menunjukkan bahawa hasil simulasi MC daripada profil kedalaman dos dan profil melintang alur adalah sepadan tepat dengan keputusan uji kaji. Keputusan terbaik profil kedalaman dos adalah pada $10 \times 10 \mathrm{~cm}^{2}$ dengan kriteria lulus $98.53 \%$. Keputusan terbaik profil melintang alur adalah pada kedalaman $10 \mathrm{~cm}$ dalam fantom air dengan kriteria lulus $88.96 \%$. Percanggahan adalah disebabkan oleh serakan zarah dan ketidaksesuaian alur utama dalam PRIMO berbanding dengan uji kaji.

Kata kunci: Kod PRIMO; pemecut linear (LINAC); perataan tanpa penurasan (FFF); simulasi Monte Carlo

\section{INTRODUCTION}

Cancer is a genetic disease caused by mutation of cell (American Cancer Society 2015). One of basic methods to treat cancer is radiotherapy (Sardari et al. 2010; Tartar 2014). Linear Accelerator (LINAC) has been widely used in radiotherapy, almost available in many hospitals and cancer centers (Konefał et al. 2015). LINAC main components in photon mode from top to bottom are target, primary collimator, flattening filter, ion chamber and secondary collimator usually called jaws. Flattening filter in a medical LINAC is used to homogenize beam profiles from the photon beam at a patient or water phantom (Mayles et al. 2007). However, in modern radiotherapy techniques such as Intensity Modulated Radiation Therapy (IMRT) and Volumetric Modulated Arc Radiotherapy (VMAT), the flattening filter was removed in order to increase dose rate and reduce the treatment time (Huang et al. 2012; Xiao et al. 2015).

Medical physicists need to deliver an absorbed dose in radiotherapy treatment with an error of less than $5 \%$. This condition can be reached only if the error of dose calculation in treatment planning system is less than $2 \%$ (Abdul Haneefa et al. 2014). Monte Carlo (MC) simulation technique has become the most powerful tool in dosimetric calculation, quality control tests and modeling of LINAC (Abdul Haneefa et al. 2014; Reis Junior et al. 2014; Tartar 2014). In the future, the speed-up of computer power every year would make the MC simulation is more capable of using for the treatment planning system in radiotherapy.

Knowledge of dose distributions in medical LINAC is required for radiation quality and treatment planning system. Two basic dose distributions in radiotherapy are 
depth dose profiles and cross beam profiles (Abdul Haneefa et al. 2014; Konefał et al. 2015). The method to determine dose distribution in medical LINAC are by experiment and MC simulation (Konefał et al. 2015). Experiments use a cube filled with water usually called water phantom. Inside the water phantom there is an ionization chamber use to scan the depth dose profiles in vertical direction and cross beam profiles in both horizontal directions. For MC simulation, head of LINAC geometry and water phantom will be modeled using a distance from target to the water surface of $100 \mathrm{~cm}$.

General code of MC simulation needed the detail of geometry and long period of simulation process. The specific code of MC simulation, PRIMO, has been introduced to simulate several types of Varian and Elekta LINACs (Rodriguez et al. 2013). Truebeam STx Varian LINAC was also provided in PRIMO code and some works on it have been published (Belosi et al. 2014; Rodriguez et al. 2015).

Truebeam STx Varian LINAC is the latest model from Varian. Several features are different with the previous Varian model such as availability of Flattening Filter Free (FFF) for photon beam (Beyer 2013). The Truebeam STx Varian LINAC is capable of delivering radiation at a faster dose rate than the previous Varian model by FFF function. This advance features make treatment time half shorter than the previous Varian model. Truebeam STx Varian LINAC is very suitable for IMRT and VMAT techniques.

In this work, we simulated 6 MV FFF Truebeam STx Varian LINAC with FakeBeam geometry model in PRIMO. Depth dose profiles for several jaws open field and cross beam profiles for various depths inside water phantom were simulated. Simulation results were compared with experimental data which were taken from Truebeam STx Varian LINAC machine in Songklanagarind Hospital.

\section{MATERIALS AND METHODS}

\section{SIMULATION}

The PRIMO code (Rodriguez et al. 2013) was used to simulate the photon beam of TrueBeam STx Varian Linear Accelerator (LINAC). Simulations were performed using 6 MV Flattening Filter Free (FFF) of photon beam with $10^{9}$ histories. The $6 \mathrm{MV}$ photon beam was chosen because it is the most frequent energy used to treat patient in Songklanagarind Hospital, Songkhla, Thailand. Initial electron beam for $6 \mathrm{MeV}$ possesses Gaussian distribution characteristic with mean energy $5.8 \mathrm{MeV}, 0.058$ FWHM (1\%) and $0.15 \mathrm{~cm}$ focal spot FWHM (Rodriguez et al. 2015). Geometry of head of TrueBeam STx Varian LINAC was provided in PRIMO code. Water phantom was modeled as place to distribute the photon beam's dose. Set up of configuration used the Source to Surface Distance (SSD) technique with a $100 \mathrm{~cm}$ distance from target to the surface of water phantom. Based on report of The American Association of Physicist in Medicine (AAPM) task group no. 105, MC simulations should make the same configuration with the experimental set up (Chetty et al. 2007). Simulation set up and detail of material used in the LINAC head was shown in Figure 1. Jaws were set for $4 \times 4$, $10 \times 10$ and $40 \times 40 \mathrm{~cm}^{2}$ open fields for measuring depth dose profiles. For the cross beam profiles jaws were set constantly at $10 \times 10 \mathrm{~cm}^{2}$ open field. The cross beam profiles were simulated on the $\mathrm{X}$ axes and calculate the relative dose inside water phantom at depth $1.5,5$ and $10 \mathrm{~cm}$.

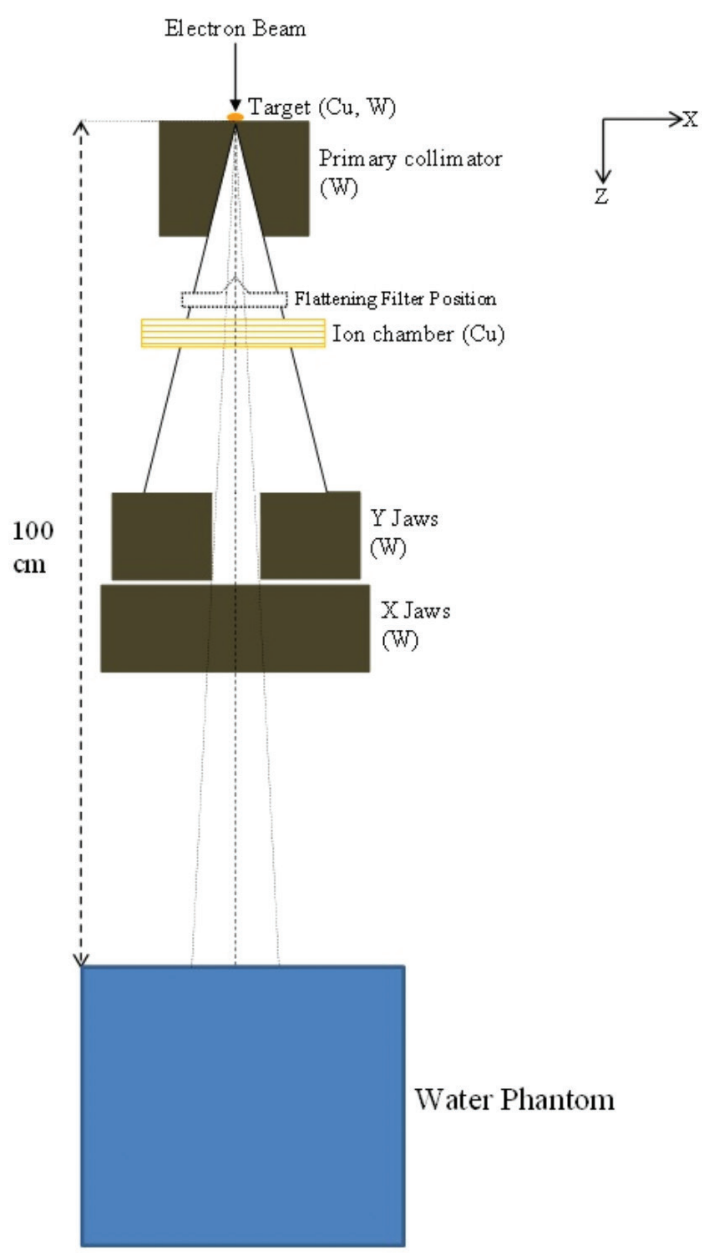

FIGURE 1 . Simple drawing of the LINAC head geometry and water phantom

\section{EXPERIMENTAL DETAILS}

Experiments were performed using water phantom and Source to Surface Distance (SSD) technique with a $100 \mathrm{~cm}$ distance from target to the surface of water. In this work, we used a commercial water phantom from IBA Dosimetry GmbH, Schwarzenbruck, Germany, named blue phantom². Dose distributions of 6 MV FFF photon beam of TrueBeam STx Varian LINAC were characterized using blue phantom ${ }^{2}$. IBA cc13 ionization chamber was used inside blue phantom ${ }^{2}$ to scan the depth dose profiles and the cross beam profiles in vertical and horizontal directions (Atarod et al. 2013; Konefał et al. 2015). 


\section{COMPARISON}

Experimental results were imported to PRIMO code for comparison of measured and calculated doses using gamma analysis proposed by Low et al. (1998). Experimental results were used as reference data and simulation results as evaluation data. Gamma index $(\Gamma)$ for experimental point $\mathrm{p}$ and the dose at that point $\mathrm{d}_{\mathrm{e}}(\mathrm{p})$ is calculated based on (1).

$$
\Gamma=\min \left\{\sqrt{\left(\frac{\Delta d_{i}}{\Delta D}\right)^{2}+\left(\frac{\Delta s_{i}}{\Delta S}\right)^{2}}\right\}
$$

where $\Delta \mathrm{D}$ is acceptance criterion for the dose difference; $\Delta \mathrm{S}$ is acceptance criterion for the distance to agreement; $\Delta \mathrm{d}_{\mathrm{i}}$ is the difference between $\mathrm{d}_{\mathrm{e}}(\mathrm{p})$ and the simulated dose at a certain point $\mathrm{p}_{i}$; and $\Delta \mathrm{s}_{\mathrm{i}}$ is the distance between $\mathrm{p}$ and $\mathrm{p}_{\mathrm{i}}$.

In this work, the lowest acceptance criteria in PRIMO used $1 \%$ for the dose difference $(\Delta \mathrm{D})$ and $1 \mathrm{~mm}$ for the distance to agreement $(\Delta S)$.

\section{RESULTS AND DISCUSSION}

The depth dose profiles and cross beam profiles are two important dosimetric parameters on the commissioning of medical Linear Accelerator (LINAC). The depth dose profiles are used for beam quality parameter while cross beam profiles are for radiation dose reliability parameter. The differences between simulation and experimental results may be caused by incompatibility of initial electron beam parameters.

\section{DEPTH DOSE PROFILES COMPARISON}

The depth dose profiles are normalized to the central axis of the beam. Measurements are taken at $4 \times 4,10 \times 10$ and $40 \times 40 \mathrm{~cm}^{2}$ jaws open field with SSD $100 \mathrm{~cm}$ technique. Open field $4 \times 4$ and $40 \times 40 \mathrm{~cm}^{2}$ are the smallest and the biggest sizes of jaws that can reachable by LINAC whereas open field $10 \times 10 \mathrm{~cm}^{2}$ is the standard operation size of jaws open field in LINAC (Abdul Haneefa et al. 2014). Measurements are taken up to depth $30 \mathrm{~cm}$ along central axis inside water phantom. Figure 2 shows the comparison for simulation results and experimental results of depth dose profiles for each jaws open field. The depth dose profiles are presented with relative dose in percent. Every dose at certain point is normalized to the maximum value as shown in (2).

$$
\text { Relative dose }(\%)=\frac{D_{p}}{D_{\max }} \times 100 \%,
$$

where $\mathrm{D}_{\mathrm{p}}$ is the dose at any position; and $\mathrm{D}_{\max }$ is the dose maximum.

The depth dose profiles curves are separated into two regions. The first region is from surface of water to a depth at maximum dose called build-up region and the second is the depth after dose maximum called equilibrium region. The detail of gamma analysis for each jaws open field is shown in Table 1. It can be seen that the difference

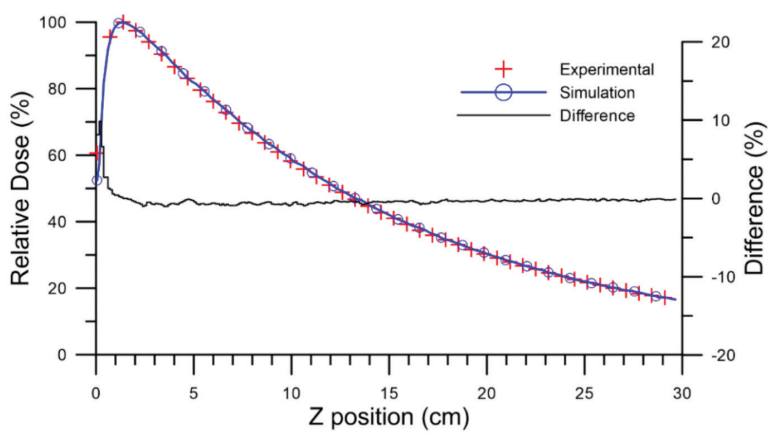

(a)

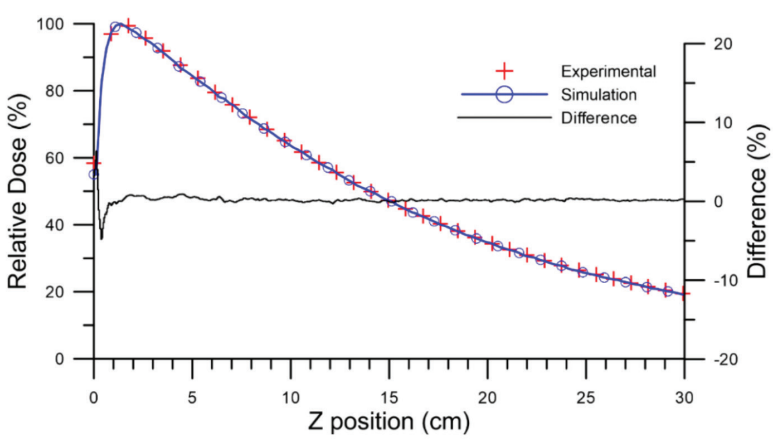

(b)

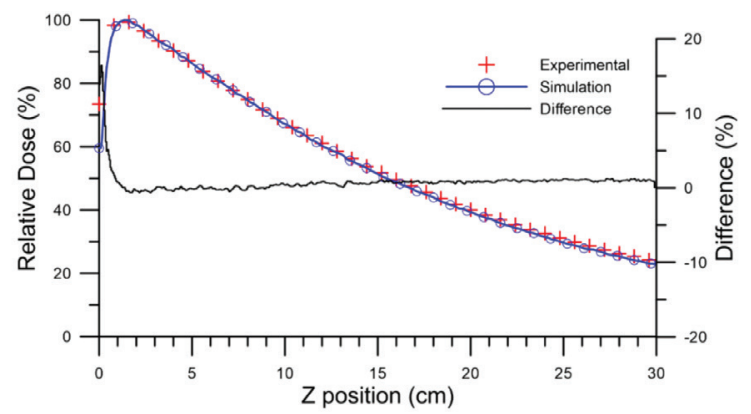

(c)

FIGURE 2. Depth dose profiles comparison for (a) $4 \times 4 \mathrm{~cm}^{2}$,

(b) $10 \times 10 \mathrm{~cm}^{2}$ and (c) $40 \times 40 \mathrm{~cm}^{2}$ jaws open field

is quite small with high percentage passing criterion of $98.40 \%$ and $98.53 \%$ at $4 \times 4$ and $10 \times 10 \mathrm{~cm}^{2}$ jaws open field, respectively, as shown in Figure 2(b). When jaws open field becomes bigger at $40 \times 40 \mathrm{~cm}^{2}$, the percentage passing criterion is lower. This is probably due to the less number of particles in the outer area are simulated and big error will be obtained.

From Table 1, the average gamma index is bigger in the build-up region than in the equilibrium region. It is because in the build-up region there are several free electrons originated and caused interactions as well, such as Compton scattering, photoelectric effect, and pair production. High energy electrons will be ejected when high energy photon (in this case $6 \mathrm{MV}$ ) interacts with water phantom. These electrons will deposit their energy to the water. The production of electrons will decrease with depth inside water phantom since photon energy fluence continuously decreased. Because of electrons fluence, the 
TABLE 1. Gamma analysis of depth dose profiles curve

\begin{tabular}{ccccc}
\hline & & \multicolumn{2}{c}{ Average gamma index } & \multirow{2}{*}{$\begin{array}{c}\text { Percentage passing } \\
\text { No }\end{array}$} \\
\cline { 3 - 4 } & Jaws open field $\left(\mathrm{cm}^{2}\right)$ & Build-up region & Equilibrium region & \\
\hline 1 & $4 \times 4$ & 1.01 & 0.12 & 98.40 \\
2 & $10 \times 10$ & 0.78 & 0.20 & 98.53 \\
3 & $40 \times 40$ & 1.20 & 0.64 & 80.97 \\
\hline
\end{tabular}

absorbed dose will increase with depth until reach the maximum.

\section{CROSS BEAM PROFILES COMPARISON}

Cross beam profiles are simulated and measured at $10 \times 10$ $\mathrm{cm}^{2}$ jaws open field, at 1.5,5 and $10 \mathrm{~cm}$ depths inside water phantom. Figure 3 shows the comparison of simulation and experimental results of cross beam profiles for each depth inside water phantom.

The comparison is normalized to the maximum value. Cross beam profiles curves can be divided into three regions. The first is inside field where the area is covered by jaws open field, the second is penumbra where the dose fall down rapidly at the beam edge and the third is outside field where the area is not covered by the jaws open field.

Gamma analyses for each depth inside water phantom as shown in Table 2, indicate that gamma indices in outside field and penumbra region are bigger than those in the inside field. This differences probably represent the number of simulated particles in which less number of simulated particles will be found in penumbra and outside field regions and result in a big statistical fluctuations in MC simulation and big gamma index (Graves et al. 2013; Saidi et al. 2013).

\section{CONCLUSION}

Monte Carlo simulation results of 6 MV Flattening Filter Free (FFF) of photon beam of TrueBeam STx Varian Linear Accelerator (LINAC) using PRIMO code show a good agreement with experimental results. The depth dose profiles give a good agreement with more than $80 \%$ passing criteria. The average gamma index in cross beam profiles are less than 0.6 in inside field region, less than 2.5 in penumbra region, and less than 0.6 in outside field region. All of gamma index use the lowest dose difference acceptance criteria of $1 \%$ and distance to agreement criteria of $1 \mathrm{~mm}$. The difference is probably caused by

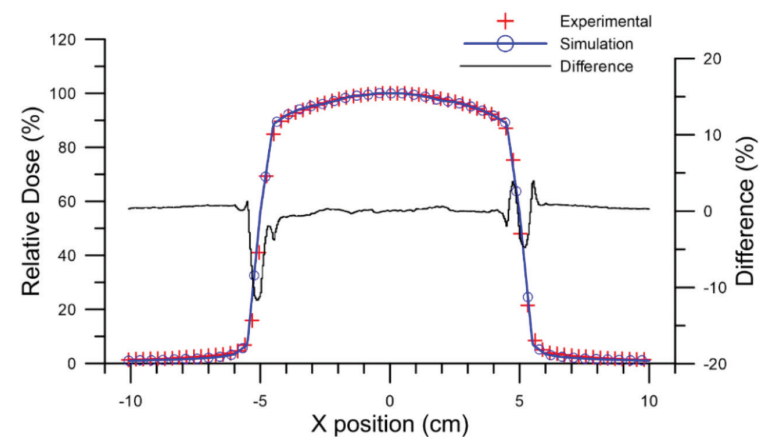

(a)

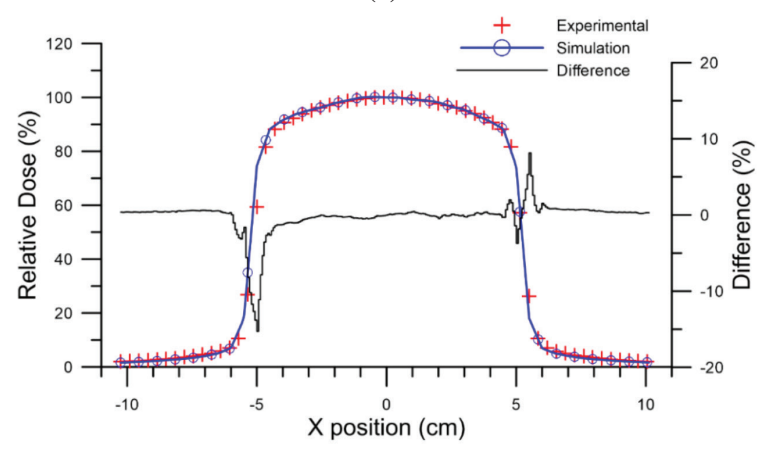

(b)

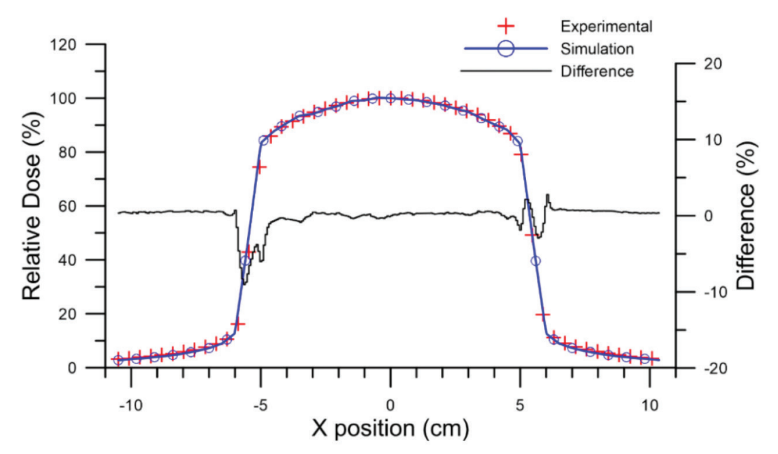

(c)

FIGURE 3. Cross beam profiles comparison for $10 \times 10 \mathrm{~cm}^{2}$ jaws open field inside water phantom at depth, (a) $1.5 \mathrm{~cm}$,

(b) $5 \mathrm{~cm}$ and (c) $10 \mathrm{~cm}$

TABLE 2. Gamma analysis for cross beam profiles

\begin{tabular}{cccccc}
\hline \multirow{2}{*}{ No } & $\begin{array}{c}\text { Depth inside water } \\
\text { phantom }(\mathrm{cm})\end{array}$ & \multicolumn{3}{c}{ Average gamma index } & \multirow{2}{*}{$\begin{array}{c}\text { Percentage passing } \\
\text { criteria }(\%)\end{array}$} \\
\cline { 3 - 4 } & 1.5 & Inside field & Penumbra region & Outside field & 87.87 \\
1 & 5 & 0.46 & 2.42 & 0.58 & 84.93 \\
3 & 10 & 0.52 & 2.09 & 0.52 & 88.96 \\
\hline
\end{tabular}


incompatibility of initial electron beam parameters between simulation and experiment. This discrepancy can be overcome by tuning of initial electron beam parameters in simulation. In conclusion, PRIMO code can be successfully used as an alternative for dosimetric calculation instead of traditional analytical treatment planning.

\section{ACKNOWLEDGEMENTS}

The authors would like to thank all medical physicists at Songklanagarind Hospital, officers from the Department of Medical Sciences, Ministry of Public Health and engineer from Varian Medical Systems for their support and assistance in this project. We thank the Department of Physics, Faculty of Science and Computer Center, Prince of Songkla University (PSU) for all facilities supports. Thailand's Education Hub for Southern Region of ASEAN Countries (TEH-AC) is acknowledged for scholarship to the first author. This work is supported by research grant from graduate school, PSU.

\section{REFERENCES}

Abdul Haneefa, K., Siji Cyriac, T., Musthafa, M.M., Ganapathi Raman, R., Hridya, V.T., Siddhartha, A. \& Shakir, K.K. 2014. FLUKA Monte Carlo for basic dosimetric studies of dual energy medical linear accelerator. Journal of Radiotherapy 46(37): 46098370.

American Cancer Society. 2015. Cancer Facts \& Figures. Atlanta, Ga: American Cancer Society.

Atarod, M., Shokrani, P. \& Azarnoosh, A. 2013. Out-of-field beam characteristics of a $6 \mathrm{MV}$ photon beam: Results of a Monte Carlo study. Applied Radiation and Isotopes 72: 182-194.

Belosi, M.F., Rodriguez, M., Fogliata, A., Cozzi, L., Sempau, J., Clivio, A., Nicolini, G., Vanetti, E., Krauss, H., Khamphan, C., Fenoglietto, P., Puxeu, J., Fedele, D., Mancosu, P. \& Brualla, L. 2014. Monte Carlo simulation of truebeam flattening-filter-free beams using varian phase-space files: Comparison with experimental data. Medical Physics 41(5): 51707.

Beyer, G.P. 2013. Commissioning measurements for photon beam data on three truebeam linear accelerators, and comparison with trilogy and clinac 2100 linear accelerators. Journal of Applied Clinical Medical Physics 14(1): 273-288.

Chetty, I.J., Curran, B., Cygler, J.E., DeMarco, J.J., Ezzell, G., Faddegon, B.A., Kawrakow, I., Keall, P.J., Liu, H., Charlie Ma, C.M., Rogers, D.W.O., Seuntjens, J., Sheikh-Bagheri, D. \& Siebers, J.V. 2007. Report of the AAPM Task Group No. 105: Issues associated with clinical implementation of Monte Carlo-based photon and electron external beam treatment planning. Medical Physics 34(12): 4818-4853.

Graves, Y.J., Jia, X. \& Jiang, S.B. 2013. Effect of statistical fluctuation in Monte Carlo based photon beam dose calculation on gamma index evaluation. Physics in Medicine and Biology 58(6): 1839-1854.

Huang, Y., Alfredo Siochi, R. \& Bayouth, J.E. 2012. Dosimetric properties of a beam quality-matched $6 \mathrm{MV}$ unflattened photon beam. Journal of Applied Clinical Medical Physics 13(4): 71-81.
Konefał, A., Bakoniak, M., Orlef, A., Maniakowski, Z. \& Szewczuk, M. 2015. Energy spectra in water for the $6 \mathrm{MV}$ $\mathrm{x}$-ray therapeutic beam generated by clinac-2300 linac. Radiation Measurements 72: 12-22.

Low, D.A., Harms, W.B., Mutic, S. \& Purdy, J.A. 1998. A technique for the quantitative evaluation of dose distributions. Medical Physics 25(5): 656-661.

Mayles, P., Nahum, A. \& Rosenwald, J-C. 2007. Handbook of Radiotherapy Physics: Theory and Practice. Boca Raton: CRC Press.

Reis Junior, J.P., Salmon, H., Menezes, A.F., Pavan, G.A., Rosa, L.A.R. \& Silva, A.X. 2014. Simulation of Siemens $\mathrm{ONCOR}^{\mathrm{TM}}$ expression linear accelerator using phase space in the MCNPX code. Progress in Nuclear Energy 70: 64-70.

Rodriguez, M., Sempau, J. \& Brualla, L. 2013. PRIMO: A graphical environment for the Monte Carlo simulation of varian and elekta linacs. Strahlentherapie Und Onkologie 189(10): 881-886.

Rodriguez, M., Sempau, J., Fogliata, A., Cozzi, L., Sauerwein, W. \& Brualla, L. 2015. A geometrical model for the Monte Carlo simulation of the truebeam linac. Physics in Medicine and Biology 60(11): N219-N229.

Saidi, P., Tenreiro, C. \& Sadeghi, M. 2013. Variance Reduction of Monte Carlo Simulation in Nuclear Engineering Field. Rijeka, Croatia: INTECH Open Access Publisher.

Sardari, D., Maleki, R., Samavat, H. \& Esmaeeli, A. 2010 Measurement of depth-dose of linear accelerator and simulation by use of Geant 4 computer code. Reports of Practical Oncology \& Radiotherapy 15(3): 64-68.

Tartar, A. 2014. Monte Carlo simulation approaches to dose distributions for $6 \mathrm{MV}$ photon beams in clinical linear accelerator. Biocybernetics and Biomedical Engineering 34(2): 90-100.

Xiao, Y., Kry, S.F., Popple, R., Yorke, E., Papanikolaou, N., Stathakis, S., Xia, P., Huq, S., Bayouth, J., Galvin, J. \& Yin, F.F. 2015. Flattening filter-free accelerators: A report from the AAPM therapy emerging technology assessment work group. Journal of Applied Clinical Medical Physics 16(3): 5219.

M. Arif Efendi, Thawat Chittrakarn \& Tripob Bhongsuwan* Department of Physics

Faculty of Science

Prince of Songkla University

90110 Hatyai City, Songkla

Thailand

M. Arif Efendi \& Amporn Funsian

Department of Radiology

Faculty of Medicine

Prince of Songkla University

90110 Hatyai City, Songkla

Thailand

*Corresponding author; email: tripop.b@psu.ac.th

Received: 31 August 2016

Accepted: 17 January 2017 